\title{
КОМУНІКАТИВНІ ВЛАСТИВОСТІ СТУДЕНТІВ-ПСИХОЛОГІВ, СХИЛЬНИХ ДО ЛІДЕРСТВА
}

\author{
Підбуцька Н. В. \\ доктор психологічних наук, \\ професор кафедри педагогіки і психології управління соціальними системами \\ Національний технічний університет «Харківський політехнічний інститут» \\ вул. Кирпичова, 2, Харків, Украӥна \\ orcid.org/0000-0001-5319-1996 \\ podbutskaya_nina@ukr.net \\ Книші А. С. \\ кандидат психологічних наук, \\ дочент кафедри педагогіки і психологї̈ управління соціальними системами \\ Національний технічний університет «Харківський політехнічний інститут» \\ вул. Кирпичова, 2, Харків, Україна \\ orcid.org/0000-0003-0211-2535 \\ n_knysh@ukr.net

\section{Богдан Ж. Б.} \\ кандидат психологічних наук, \\ доцент кафедри педагогіки і психології управління сочіальними системами \\ Національний технічний університет «Харківський політехнічний інститут» \\ вул. Кирпичова, 2, Харків, Україна \\ orcid.org/0000-0003-1560-9516 \\ janna.bogdan1979@gmail.com \\ Чебакова Ю. Г. \\ кандидат педагогічних наук, \\ доцент кафедри педагогіки і психологї̈ управління сочіальними системами \\ Національний технічний університет «Харківський політехнічний інститут» \\ вул. Кирпичова, 2, Харків, Украӥна \\ orcid.org/0000-0001-9317-8585 \\ chebakova.khpi@gmail.com
}

\begin{abstract}
Ключові слова: лідерство, психологи, комунікативні властивості, професійний розвиток, майбутні фахівиіi.
\end{abstract}

Дослідження присвячене темі комунікативних властивостей студентівпсихологів, що схильні до лідерства. Тема дослідження зумовлена популярністю спеціальності «Психологія», що зростає, і необхідністю вдосконалення освітніх програм не тільки в напрямі забезпечення ключових фахових компетентностей, а й у напрямі розвитку soft skills, до яких відносяться лідерство та комунікативні здібності. Акцент робиться на необхідності визначення особливостей комунікативних особливостей майбутніх психологів схильних до лідерства 3 метою подальшої розробки індивідуалізованих програм розвитку лідерства студентів цього професійного напрямку. 
У дослідженні взяли участь 60 студентів 3-4 курсів, що навчаються на освітній програмі «Психологія». У дослідженні використані методики: багатофакторний опитувальник лідерства Б. Басса, методика діагностики міжособистісних відносин Т. Лірі, п’ятифакторний опитувальник особистості Р. Маккрає і Т. Коста.

За результатами дослідження визначено, що більшість студентів має середній рівень лідерських якостей. Усі фактори трансформаційного лідерства добре розвинені в психологів, але найбільше виражені вплив та управління. Домінуючими типами міжособистісних взаємовідносин у студентів із високим рівнем лідерства $є$ авторитарний і товариський стиль, а 3 низьким - товариський та альтруїстичний. Особистісні характеристики психологів: із високим рівнем лідерства: екстраверсія (оптимістичні, активні й енергійні), прихильність (добрі та чуйні); 3 низьким рівнем: інтроверсія (не впевнені в собі, замкнуті й розсудливі), відособленість (самостійні, незалежні й холодні в ставленні до інших). В обох досліджуваних групах виявлені самоконтроль (відповідальні, точні й наполегливі), емоційна стійкість (емоційно зрілі, спокійні й реалістичні) та експресивність (емоційність і легке ставлення до життя).

\title{
COMMUNICATIVE TRAITS OF STUDENTS-PSYCHOLOGISTS WITH TENDENCY TO LEADERSHIP
}

\author{
Pidbutska N. V. \\ Doctor of Psychological Sciences, \\ Professor at the Department of Pedagogy \\ and Psychology of Social Systems Management \\ National Technical University "Kharkiv Polytechnic Institute" \\ Kirpichova str., 2, Kharkiv, Ukraine \\ orcid.org/0000-0001-5319-1996 \\ podbutskaya_nina@ukr.net
}

Knysh A. Ye.

Ph.D. in Psychology,

Associate Professor at the Department of Pedagogy

and Psychology of Social Systems Management

National Technical University "Kharkiv Polytechnic Institute"

Kirpichova str., 2, Kharkiv, Ukraine

orcid.org/0000-0003-0211-2535

n_knysh@ukr.net

Bogdan Z. B.

Ph.D. in Psychology,

Associate Professor at the Department of Pedagogy

and Psychology of Social Systems Management

National Technical University "Kharkiv Polytechnic Institute"

Kirpichova str., 2, Kharkiv, Ukraine

orcid.org/0000-0003-1560-9516

janna.bogdan1979@gmail.com 


\author{
Chebakova Y. H. \\ Ph.D. in Pedagogy, \\ Associate Professor at the Department of Pedagogy and Psychology of Social Systems Management \\ National Technical University "Kharkiv Polytechnic Institute" \\ Kirpichova str., 2, Kharkiv, Ukraine \\ orcid.org/0000-0001-9317-8585 \\ chebakova.khpi@gmail.com
}

Key words: leadership, psychologists, communicative properties, professional development, future specialists.
The research is devoted to the topic of communicative traits of studentspsychologists who are inclined to leadership. The research topic is due to the growing popularity of the specialty "Psychology" and the need to improve educational programs not only in the direction of providing key professional competencies, but also in the development of soft skills, which include leadership and communication skills. Emphasis is placed on the need to determine the features of communicative skills of future psychologists inclined to leadership in order to further develop individualized programs for leadership development of students in this professional field.

The study involved 60 students of 3-4 courses studying in the educational program "Psychology". The following methods were used in the study: B. Bass's multifactor questionnaire of leadership, T. Leary's method of diagnostics of interpersonal relations, R. McCray's and T. Costa's five-factor personality questionnaire.

According to the results of the study, it was determined that most students have an average level of leadership qualities. All factors of transformational leadership are well developed in psychologists, but the most pronounced are influence and management. The dominant types of interpersonal relationships in students with a high level of leadership are authoritarian style and friendly, and with low - friendly and altruistic. Personal characteristics of psychologists: with a high level of leadership: extraversion (optimistic, active and energetic), commitment (kind and sensitive); with a low level: introversion (insecure, closed and sensible), isolation (independent, independent and cold in relation to others). In both study groups were found: self-control (responsible, accurate and persistent), emotional stability (emotionally mature, calm and realistic) and expressiveness (emotionality and easy attitude to life).
Постановка проблеми. Останніми роками психологія перетворилася в один із найбільш популярних напрямів професійної підготовки й міцно тримається в десятці найбільш популярних серед абітурієнтів професій, за даними Міністерства освіти і науки України. Причин такої популярності декілька: невелика кількість предметів, пов'язаних із «точними» науками, що викликають складнощі в більшості абітурієнтів; романтизація професії психолога; бажання розібратися в собі; бажання допомогти іншим; спрямованість на саморозвиток. Одним із найбільш актуальних напрямів такого саморозвитку є розвиток лідерських якостей.

Лідерські якості є одними з найбільш затребуваних, адже вони пов'язані не тільки зі здатністю до управління іншими людьми, а й із самоорганізацією та спрямованістю на успіх. Згідно з остан- німи дослідженнями (М. Хекман, К. Джонсон, Р. Фрідер), лідерські здібності міцно пов'язані 3 особистісними рисами та розвиваються в контексті розвитку комунікативних характеристик особистості $[5 ; 6]$. У цьому контексті надзвичайного значення набуває визначення комунікативних характеристик, які пов'язані з схильністю до лідерства майбутніх студентів-психологів, що дасть змогу розробити й упровадити сучасні програми розвитку лідерства в майбутніх фахівців цієї сфери.

Зв'язок із важливими науковими чи практичними завданнями. Тема дослідження пов'язана 3 важливим практичним завданням, а саме розвитком soft skills майбутніх психологів, зокрема здатністю до лідерства. Щорічно заклади вищої освіти України випускають сотні студентів, що мають диплом психолога, але далеко не всі з них 
здатні реалізуватися в професії. Розвиток здатності до лідерства представників цієї групи сприяв би підвищенню їхньої адаптивності, спрямованості на успіх, готовності до подолання перешкод. Розробка ефективних програм розвитку лідерства майбутніх психологів можлива лише за умови уточнення зв'язків між схильністю до лідерства й іншими особистісними характеристиками.

Аналіз останніх досліджень і публікацій. Тема лідерства активно досліджується у світі останні сто років, але ії популярність у середовищі вітчизняних науковців зросла лише в останні два десятиліття. До теми лідерства в процесі підготовки майбутніх психологів звертаються педагоги, психологи та соціологи.

Аналіз закордонних досліджень указує на зосередженість науковців на вивченні ролі лідерства в різних сферах діяльності психолога.

Р. Ріджіо зосереджує увагу на можливостях психологів у «викладанні лідерства». Дослідник доводить, що навчати інших бути лідерами є здатністю, що притаманна будь-якому психологу. Він пов'язує це 3 тим, що психологи $є$ природними лідерами завдяки рівню розвитку їхніх комунікативних і соціальних навичок, емоційному інтелекту. Володіючи навичками лідера, психологи завдяки здатності до рефлексії добре розуміють «механіку» лідерства та можуть без проблем навчати цього інших [9]. Головним у контексті дослідження $€$ визначення зв'язків між лідерством і комунікативними здібностями психологів.

А. Ванг із колегами дослідив основні виклики, 3 якими зіштовхуються психологи-лідери, чия діяльність пов'язана 3 управлінням. Серед основних проблем прояву лідерства дослідники виділяють погане розуміння себе, нездатність донести свою думку до послідовників, надмірну зосередженість на собі та своїх переживаннях. Якщо психолог-управлінець має такі проблеми, прояв його лідерства буде залишатися під великим питанням. Дослідники роблять висновок, що здатність до лідерства не можна розвивати ізольовано від інших особистісних рис і здатностей, особливо тих, що пов'язані з комунікацією [11].

С. Шульман, Р. Фасінгер, Дж. Гуд, А. Хьюітт із колегами займаються вивченням прояву лідерства в психологічному консультуванні. У дослідженнях можна знайти деякі спільні висновки, а саме: психолог-консультант має володіти навичками лідера, бо тільки в цьому випадку клієнти будуть готовими довіряти психологу й «слідувати» за ним у пошуках себе; 2) лідерство є складним особистісним утворенням, що пов'язане з особистісними рисами та може бути розвиненим у ході навчання і тренінгів $[7 ; 10]$.

Дж. Арендт із колегами дослідив вплив комунікативних здібностей на успішність лідерства пси- хологів. Дослідник довів, що психологи-лідери, які володіють високим рівнем самоусвідомлення й розвиненими комунікативними здібностями, $€$ більш успішними лідерами, що проявляється в більшій задоволеності їхніх послідовників своєю діяльністю під управлінням психолога-лідера [3]. Таким чином, ми бачимо ще один доказ важливості комунікативних характеристик у процесі реалізації лідерства.

К. Йохансен та Е. Бек досліджували роль стратегічної комунікації в діяльності лідерів. Ними визначено, що лідеру недостатньо бути лише комунікабельною людиною. Він має володіти стратегічним типом мислення й уміти транслювати свої думки послідовникам таким чином, щоб вони могли усвідомити не тільки актуальні завдання, а й майбутню перспективу діяльності. Дослідники також доходять висновку щодо важливості розвитку стратегічної комунікації майбутніх лідерів [8].

Дослідження вітчизняних дослідників переважно зосереджені на визначенні лідерських якостей майбутніх психологів.

О. Корякін досліджує педагогічні умови формування конструктивного лідерства майбутніх магістрів гуманітарного профілю [1]. В. Бондаренко й О. Романовський вивчають педагогічні умови формування лідерських якостей майбутніх психологів [2]. В обох дослідженнях можна визначити спільні риси, а саме: визнання важливості лідерства в діяльності сучасних психологів; виділення комунікативних якостей як таких, що пов'язані $з$ лідерством. Разом із тим у перерахованих дослідженнях зв'язок між лідерством і комунікативними здібностями доводиться лише на основі теоретичного аналізу.

Виділення не вирішених раніше частин загальної проблеми. Проведений аналіз останніх досліджень указує на недостатню дослідженість саме у вітчизняній науці характеру зв'язків між проявами лідерства та комунікативними здібностями майбутніх психологів. Подібні зв'язки $\epsilon$ дуже добре дослідженими в закордонній психологіiі. Та маємо зазначити, що зміст освітніх програм та особливості розвитку майбутніх психологів в Україні й закордоном мають свої відмінності. Щоб займатися розробкою програм розвитку лідерства майбутніх психологів, ми маємо емпірично вивчити особливості прояву комунікативних здібностей у студентів, які схильні до лідерства.

Мета роботи полягає у визначенні комунікативних рис, що притаманні майбутнім психологам зі схильністю до лідерства.

Виклад основного матеріалу. Дослідження здійснено на базі кафедри педагогіки і психології управління соціальними системами Національного технічного університету «Харківський полі- 
технічний інститут». У дослідженні взяли участь 60 студентів 3-4 курсів, що навчаються на освітній програмі «Психологія».

У дослідженні використано методики:

1. Багатофакторний опитувальник лідерства Б. Басcа.

2. Методика діагностики міжособистісних відносин Т. Лірі.

3. П'ятифакторний опитувальник особистості Р. Маккрає і Т. Коста.

3 метою визначення комунікативних особливостей студентів, схильних до лідерства, проведено дослідження з використанням психологічних методик, які згадані вище. Отримані результати будуть наведені нижче.

Отримані дані свідчать про те, що $40 \%$ студентів-психологів мають високий рівень схильності до лідерства, це означає, що вони прокладають нові шляхи, є мрійниками і провидцями. Ці якості лідера мотивують, надихають людей на дії далеко за межею того рівня, на якому вони діяли раніше. Середній рівень мають 53,33\% студентів, тобто вони можуть посилювати мотивацію, моральний дух і продуктивність послідовників за допомогою різних механізмів, але приймати ризиковані дії вони готові залежно від ситуації. Такі люди спочатку добре все обмірковують і тільки потім діють. Низький рівень мають $6,67 \%$ респондентів, у них є здатності та якості, притаманні трансформаційному лідеру, але їх потрібно розвивати. Дуже високого рівня й дуже низького не виявлено в цій групі респондентів.
Кожен 3 опитуваних студентів схильний до лідерства, але для того, щоб у подальшому стати керівником, за яким будуть слідувати люди, або ж просто вміти знаходити нестандартні рішення проблем, треба постійно розвиватися й самовдосконалюватися.

Далі на рисунку 1 зображено результати рівня за шкалами методики «Багатофакторний опитувальник лідерства» Б. Басса й інших.

Узагальнюючи результати, можемо побачити, що студенти вміють підбирати стиль управління залежно від групи та ситуації, мають вплив і здатні надихати інших на досягнення спільної мети. Вони $є$ авторитетами серед свого оточення. Студенти-психологи розуміють, що треба мотивувати людей, і роблять це, але не завжди ефективно. Організування групової роботи теж може викликати труднощі, та вони легко їх долають. Творчий i креативний підхід до ситуації потрібно розвивати, щоб із легкістю долати труднощі. Можна відмітити те, що на цей момент респонденти більш зацікавлені своїми ідеями й тим, як їх можна втілити в життя, а не на самих людях та індивідуальному підході до них, тому й вийшли такі дані.

Щодо комунікативних здібностей, то опитувані з легкістю формують довіру до себе, розповідають ідеї та спонукають до дії, адаптують стиль спілкування залежно від групи й ефективно взаємодіють 3 оточуючими. Результати дослідження домінуючого типу відносин із використанням методики Т. Лірі «Діагностика міжособистісних відносин» зображено на рисунку 2.

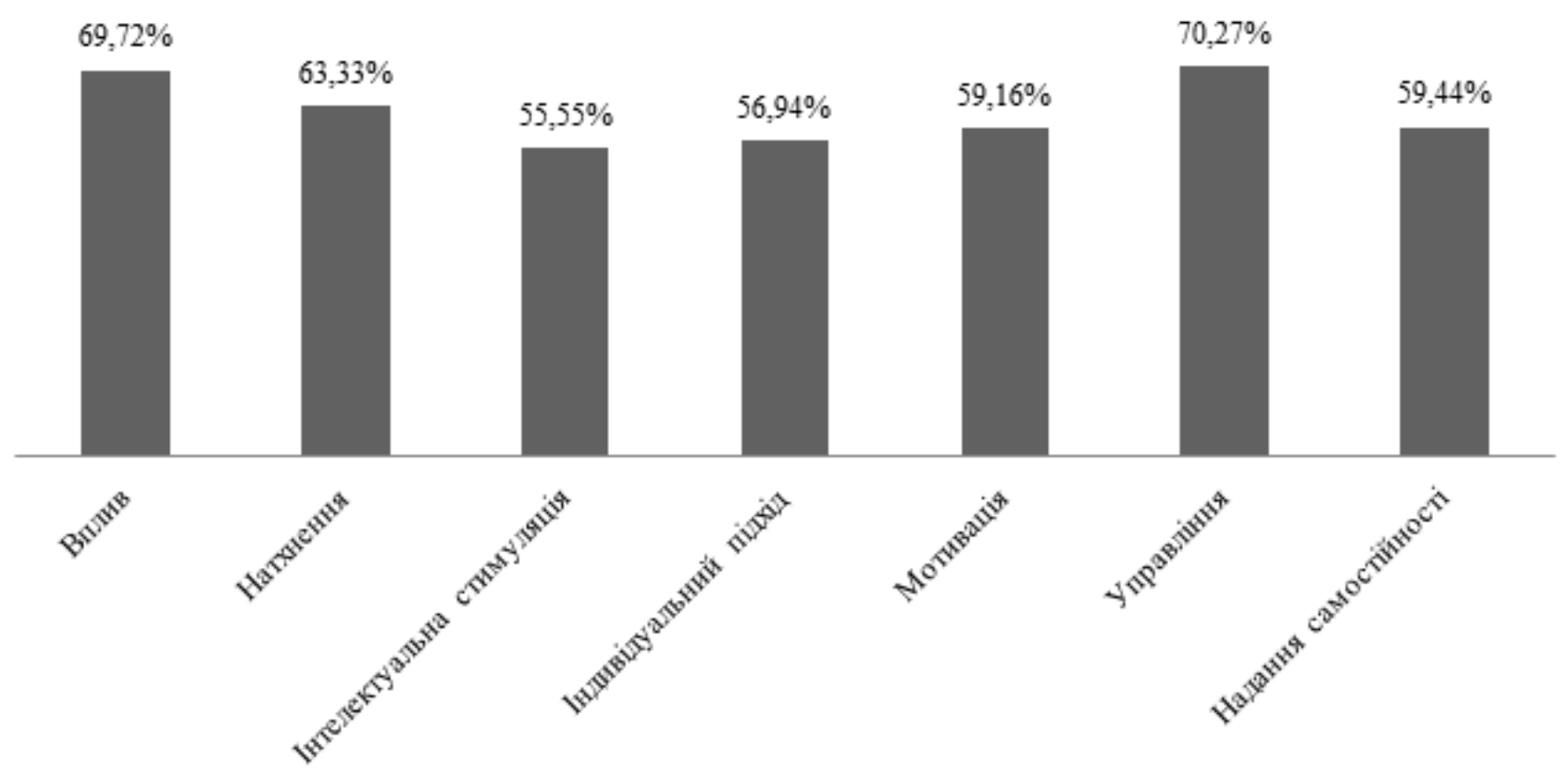

Рис. 1. Вираженість факторів трансформаційного лідерства (у \%) 


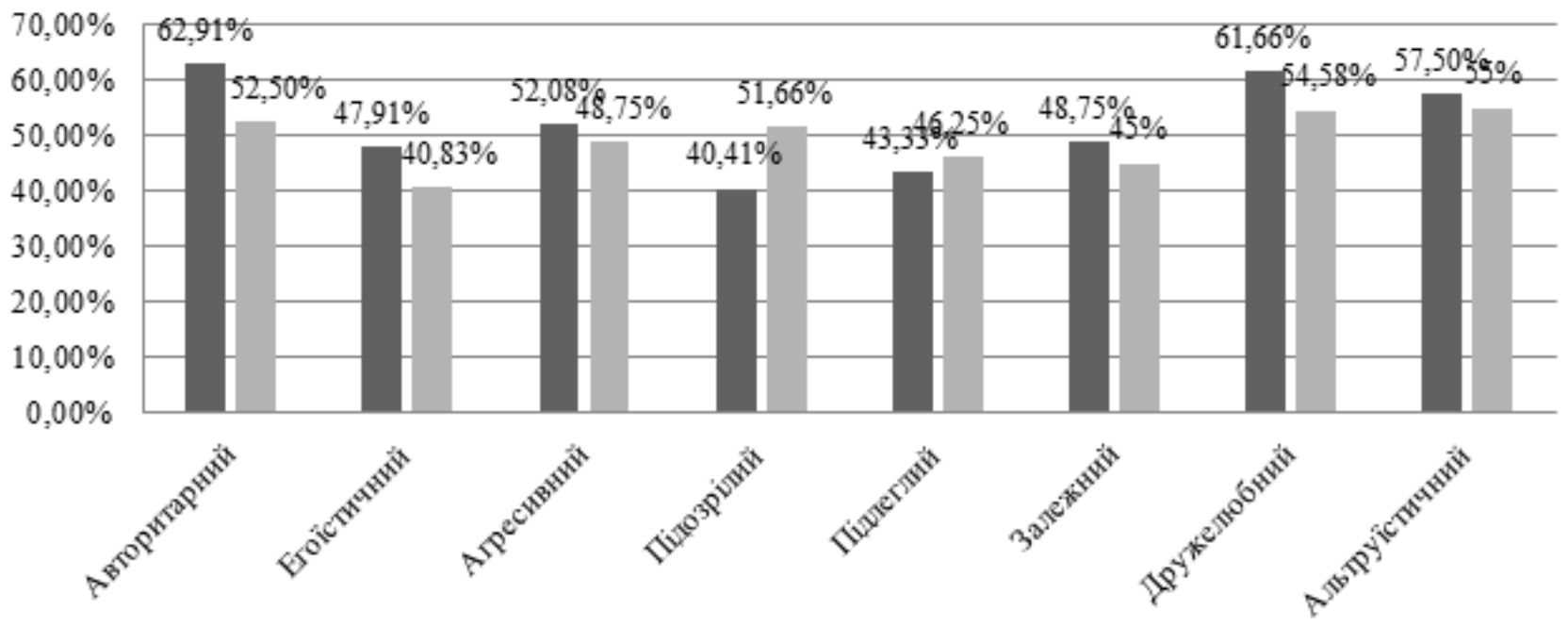

п Високий рівень лідерства Шизький рівень лідерства

Рис. 2. Порівняння поведінки в міжособистісній взаємодії студентів з високим і низьким рівнями трансформаційного лідерства (у \%)

За даними результатами, визначено й установлено індекс домінування та товариськості:

- студенти 3 високим рівнем лідерства: $80 \%$ отримали позитивний результат за формулою «Домінування» та 53,33\% - за формулою «Товариськості», це означає, що більшість психологів прагне до лідерства в спілкуванні, а до товариськості звертається не завжди;

- студенти з низьким рівнем лідерства: $66,66 \%$ отримали позитивний результат за формулою «Товариськість» і $60 \%$ - «Домінуванню», це означає, що ця група респондентів прагне до встановлення доброзичливих взаємин і співпраці 3 оточуючими, лідерство не $\epsilon$ основним фактором установлення зв'язків.

Домінуючими типами поведінки в студентів із високим рівнем лідерства $є$ авторитарний стиль i товариський, а з низьким - товариський та альтруїстичний. Кожен доповнює один одного, має свій вплив на середовище й оточуючих. Перша група психологів оптимістична, активна, має високу мотивацію, прагне займати лідерську позицію та вести за собою людей. Опитувані залежні від думки оточуючих, але водночас не сприймають критику на свою адресу. Друга група прагне всім допомогти, дуже відповідальна, люб'язна 3 усіма,

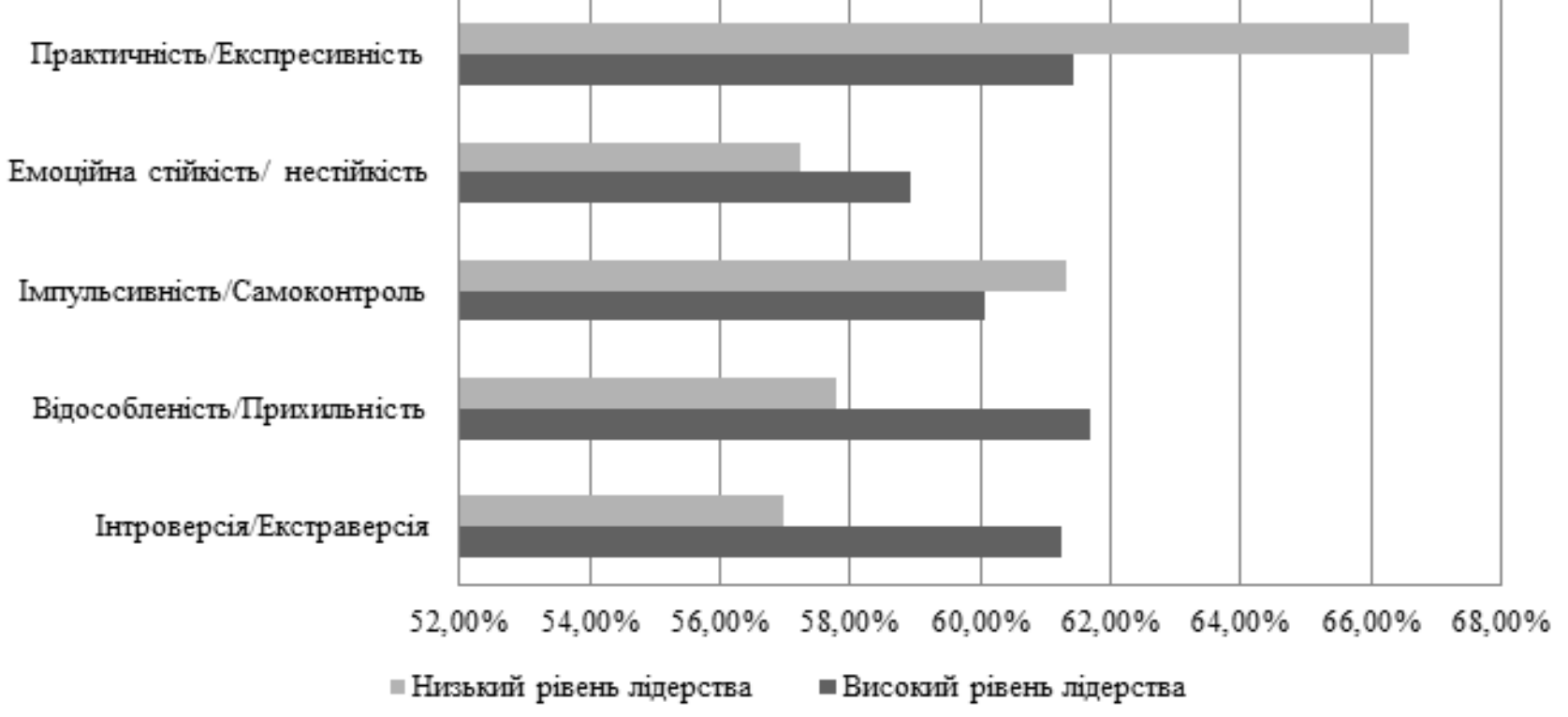

Рис. 3. Порівняльна гістограма вираженості особистісних рис у студентів із високим і низьким рівнем лідерства (у \%) 
орієнтована на прийняття й соціальне схвалення. Обидві групи мають свої особливості, за домінуючим типом міжособистісних взаємин легко відрізнити групу з високим і низьким рівнями лідерства.

Далі на рисунку 3 зображено результати методики Р. Маккрає і Т. Кости «П'ятифакторний опитувальник особистості».

В обох групах 3 високим і низьким рівнем лідерства переважає експресивність $(61,42 \%$ та $66,57 \%$ ), але в респондентів 3 низьким рівнем вона виражена найяскравіше. Варто зауважити, що практичність у психологів не виявлена. Такі люди емоційні й реалістичні, уникають рутинної роботи. Дуже легко відносяться до життя та відчувають безтурботність. Вони частіше довіряють своїм почуттям і інтуїції, ніж здоровому глузду, мало звертають уваги на поточні повсякденні справи й обов'язки.

Висновки. Проведений емпіричний аналіз дав змогу визначити комунікативні особливості студентів-психологів схильних до лідерства, а саме:

- більшість студентів має середній рівень лідерських якостей;
- усі фактори трансформаційного лідерства добре розвинені в психологів, але найбільше виражені вплив та управління;

- домінуючими типами міжособистісних взаємовідносин у студентів із високим рівнем лідерства $\epsilon$ авторитарний і товариський стилі, а 3 низьким - товариський та альтруїстичний;

- особистісні характеристики психологів: із високим рівнем лідерства: екстраверсія (оптимістичні, активні та енергійні), прихильність (добрі та чуйні); 3 низьким рівнем: інтроверсія (не впевнені в собі, замкнуті та розсудливі), відособленість (самостійні, незалежні й холодні в ставленні до інших). В обох досліджуваних групах виявлені самоконтроль (відповідальні, точні й наполегливі), емоційна стійкість (емоційно зрілі, спокійні й реалістичні) та експресивність (емоційність і легке ставлення до життя).

Перспективи подальших досліджень полягають в уточненні зв'язків між проявами лідерства й особистісними характеристиками майбутніх психологів з метою розробки та впровадження в їхню підготовку індивідуалізованих програм розвитку лідерства.

\section{ЛІТЕРАТУРА}

1. Корякін О.О. Педагогічні умови розвитку конструктивного лідерства майбутніх магістрів гуманітарного профілю у процесі професійної підготовки : автореф. дис. ... канд. пед. наук : 13.00 .04 «Теорія і методика проф. освіти». Суми : СумДПУ ім. А.С. Макаренка, 2018. 20 с.

2. Романовський О.Г., Бондаренко В.В. Інноваційне формування повного спектру особистісних якостей лідера у всіх видах професійної діяльності на прикладі майбутніх психологів. Теорія $i$ практика управління сочіальними системами. 2017. № 2. С. 3-13.

3. Arendt J.F., Pircher Verdorfer A., Kugler K.G. Mindfulness and leadership: Communication as a behavioral correlate of leader mindfulness and its effect on follower satisfaction. Frontiers in psychology. 2019. № 10. P. 667.

4. Fassinger R.E., Good G.E. Academic leadership and counseling psychology: Answering the challenge, achieving the promise. The Counseling Psychologist. 2017. № 45(6). P. 752-780.

5. Frieder R.E., Wang G., Oh, I.S. Linking job-relevant personality traits, transformational leadership, and job performance via perceived meaningfulness at work: A moderated mediation model. Journal of Applied Psychology. 2018. № 103(3). P. 324.

6. Hackman M.Z., Johnson C.E. Leadership: A communication perspective. Waveland press. 2013. P. 530.

7. Hewitt A.A., Watson L.B., DeBlaere C., Dispenza F., Guzmán C.E., Cadenas G., Ferdinand L. Leadership development in counseling psychology: Voices of leadership academy alumni. The Counseling Psychologist. 2017. № 45(7). P. 992-1016.

8. Johansson C., Bäck E. Strategic leadership communication for crisis network coordination. International Journal of Strategic Communication. 2017. № 11(4). P. 324-343.

9. Riggio R.E. Teaching leadership: Most any psychologist can do it. Teaching of Psychology. 2015. № 42(4). P. 361-367.

10. Shullman S.L. Leadership and counseling psychology: Dilemmas, ambiguities, and possibilities. The Counseling Psychologist. 2017. № 45(7). P. 910-926.

11. Wang A.Y., Frederick C.M. Leadership in higher education: Opportunities and challenges for psychologist-managers. The Psychologist-Manager Journal. 2018. № 21(3). P. 197.

\section{REFERENCES}

1. Koriakin O.O. Pedahohichni umovy rozvytku konstruktyvnoho liderstva maibutnikh mahistriv humanitarnoho profiliu u protsesi profesiinoi pidhotovky [Pedagogical conditions for the development of constructive leadership of future masters of the humanities in the process of professional training] : avtoref. dys.... 
kand. ped. nauk : spets. 13.00.04 - teoriia i metodyka prof. osvity. Sumy: SumDPU im. A. S. Makarenka, 2018. 20 s. [In Ukrainian].

2. Romanovskyi O.H., Bondarenko V.V. Innovatsiine formuvannia povnoho spektru osobystisnykh yakostei lidera u vsikh vydakh profesiinoi diialnosti na prykladi maibutnikh psykholohiv [Innovative formation of the full range of personal qualities of a leader in all types of professional activities on the example of future psychologists]. Teoriia i praktyka upravlinnia sotsialnymy systemamy. 2017. № 2. S. 3-13 [In Ukrainian].

3. Arendt J.F., Pircher Verdorfer A., Kugler K.G. Mindfulness and leadership: Communication as a behavioral correlate of leader mindfulness and its effect on follower satisfaction. Frontiers in psychology. 2019. № 10. P. 667.

4. Fassinger R.E., Good G.E. Academic leadership and counseling psychology: Answering the challenge, achieving the promise. The Counseling Psychologist. 2017. № 45(6). P. 752-780.

5. Frieder R.E., Wang G., Oh, I.S. Linking job-relevant personality traits, transformational leadership, and job performance via perceived meaningfulness at work: A moderated mediation model. Journal of Applied Psychology, 2018. № 103(3). P. 324.

6. Hackman M.Z., Johnson C.E. Leadership: A communication perspective. Waveland press. 2013. P. 530.

7. Hewitt A.A., Watson L.B., DeBlaere C., Dispenza F., Guzmán C.E., Cadenas G., Ferdinand L. Leadership development in counseling psychology: Voices of leadership academy alumni. The Counseling Psychologist. 2017. № 45(7). P. 992-1016.

8. Johansson C., Bäck E. Strategic leadership communication for crisis network coordination. International Journal of Strategic Communication. 2017. № 11(4). P. 324-343.

9. Riggio R.E. Teaching leadership: Most any psychologist can do it. Teaching of Psychology. 2015. № 42(4). P. 361-367.

10. Shullman S.L. Leadership and counseling psychology: Dilemmas, ambiguities, and possibilities. The Counseling Psychologist. 2017. № 45(7). P. 910-926.

11. Wang A.Y., Frederick C.M. Leadership in higher education: Opportunities and challenges for psychologist-managers. The Psychologist-Manager Journal. 2018. № 21(3). P. 197. 